\title{
Desain Sistem Monitoring State of Charge Baterai pada Charging Station Mobil Listrik Berbasis Fuzzy Logic Dengan Mempertimbangkan Temperalture
}

\author{
Ahmad Faiz Farizy, Dimas Anton Asfani, dan Soedibjo \\ Jurusan Teknik Elektro, Fakultas Teknologi Industri, Institut Teknologi Sepuluh Nopember (ITS) \\ Jl. Arief Rahman Hakim, Surabaya 60111 \\ e-mail: ahmadfaizfarizy@yahoo.com, anton@ee.its.ac.id
}

\begin{abstract}
Abstrak- Baterai memiliki peran penting dalam perkembangan kebutuhan energi. Peforma baterai yang baik, akan mendukung perangkat yang ditunjangnya. Energi yang dapat disimpan baterai jumlahnya terbatas, maka baterai akan mengalami siklus charge dan discharge. Proses charge dan discharge yang tidak tepat dapat menyebabkan peforma baterai menurun. Oleh karena itu manajemen baterai diperlukan agar peforma baterai dapat mencapai maksimal. Salah satu aspek manajemen baterai adalah pemantauan state of charge yang merupakan rasio kapasitansi energi yang tersedia dengan kapasitas energy maksimum. Salah satu metode untuk mengestimasi state of charge adalah metode fuzzy logic yaitu dengan menilai input dan output system dari hasil pengamatan. Dalam tugas akhir ini akan dilakukan analisis dan monitoring baterai terkait proses charge discharge pada baterai agar diperoleh state of charge yang akurat sehingga membuat baterai tidak cepat rusak. Hasil monitoring dan analisis baterai menunjukkan bahwa state of charge pada baterai telah diukur secara akurat dan bisa memperkirakan kerusakan baterai. Akan tetapi pada tugas akhir ini masih belum dapat dilakukan perkiraan umur dan kerusakan baterai.
\end{abstract}

Kata Kunci- VRLA gel baterai, proteksi, monitoring, state of charge, charging, discharging.

\section{PENDAHULUAN}

$\mathrm{P}$ ERKEMBANGAN memanfaatkan energi terbarukan semakin banyak dikembangkan. Di era mendatang, penggunaan PHEVs (Plug-in Electrical Vehicle) atau stasiun pengisian kendaraan listik diperkirakan akan mengalami peningkatan pesat. Hal ini didukung dengan adanya isu terkait menipisnya persediaan minyak dunia, sehingga perlu adanya penerapan kendaraan yang ramah lingkungan [1].

Salah satu elemen penting pada stasiun pengisian kendaraan listrik adalah battery bank. Elemen ini digunakan sebagai tempat penyimpan energi listrik dari output photovoltaic (PV) ketika operasi stand alone. Sehingga, kondisi baterai harus dipastikan selalu terisi penuh. Teknologi pengisian baterai sendiri dibedakan menjadi 3, yaitu metode arus konstan, metode tegangan konstan, dan metode pulsa. Sementara itu, proses pengisian baterai sendiri dapat dibedakan menjadi 4 jenis, yaitu slow charge, rapid charge, fast charge, dan ultrafast charge [3].

Namun, proses charge-discharge pada baterai jenis ValveRegulated Lead-Acid tipe gel (VRLA gel) dengan waktu yang cepat tidak sepenuhnya menguntungkan karena memiliki dampak negatif bagi baterai, antara lain dapat memperpendek usia baterai akibat overcharge dan overdischarge dari proses charge-discharge baterai yang kurang diperhatikan [4].

Berdasarkan hal tersebut, maka diperlukan estimasi state of charge yang akurat, sehingga mampu mendeteksi ketika batas atas tegangan pengisian baterai telah tercapai untuk mencegah baterai dari kerusakan overcharge. Selain itu, batas bawah dari tegangan baterai juga harus diperhatikan agar tidak terjadi overdischarge.

\section{DASAR TEORI}

\section{A. Baterai}

Baterai merupakan sebuah peralatan yang dapat mengubah energi Baterai listrik adalah alat yang terdiri dari 2 atau lebih sel elektrokimia yang mengubah energi kimia yang tersimpan menjadi energi listrik. Tiap sel memiliki kutub positif (katoda) dan kutub negatif (anoda). Kutub yang bertanda positif menandakan bahwa memiliki energi potensial yang lebih tinggi daripada kutub bertanda negatif. Kutub bertanda negatif adalah sumber elektron yang ketika disambungkan dengan rangkaian eksternal akan mengalir dan memberikan energi ke peralatan eksternal. Ketika baterai dihubungkan dengan rangkaian eksternal, elektrolit dapat berpindah sebagai ion didalamnya, sehingga terjadi reaksi kimia pada kedua kutubnya. Perpindahan ion dalam baterai akan mengalirkan arus listrik keluar dari baterai sehingga menghasilkan kerja.[1] Meski sebutan baterai secara teknis adalah alat dengan beberapa sel, sel tunggal juga umumnya disebut baterai

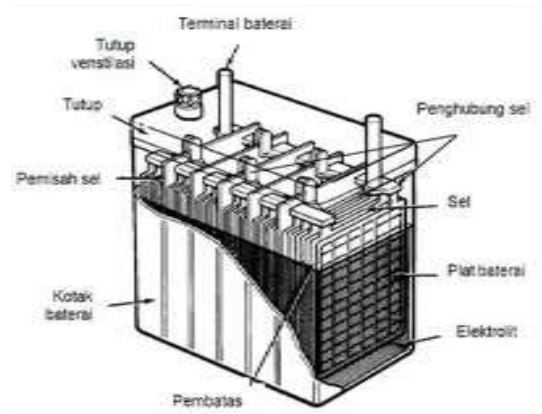

Gambar 1. Bagian pada baterai

\section{B. State of Charge}

SOC didefinisikan sebagai rasio total kapasitas energi yang dapat digunakan dari sebuah baterai dengan kapasitas baterai seluruhnya. SOC menggambarkan energi yang tersedia dan dituliskan dalam presentase sesuai beberapa referensi, terkadang dianggap sebagai nilai kapasitas dari baterai. Cara 
mengukur SOC dari baterai dapat dilakukan dengan 3 cara, yaitu:

1. Pengukuran secara langsung, dapat dilakukan jika baterai dapat di-discharge pada nilai yang konstan dan pengukuran

2. Pengukuran Specific Grafity (SG), cara ini bergantung pada perubahan pengukuran dari berat bahan kimia aktif.

3. Perkiraan SOC berdasarkan tegangan, dengan mengukur tegangan cell baterai sebagai das ar untuk perhitungan SOC atau sisa kapasitas. Hasil dapat berubah tergantung pada level tegangan nyata, suhu, nilai discharge, dan umur cell.

\section{Karakteristik Baterai Valve Regulated Lead Acid (VRLA)}

Baterai ini tidak memiliki caps/ katup, tidak ada akses ke elektrolit dan total sealed. Dengan demikian baterai jenis ini tidak memerlukan maintenance. Baterai Deep Cycle, adalah baterai yang cocok untuk sitem solar cell, karena dapat discharge sejumlah arus listrik secara konstan dalam waktu yang lama. Umumnya baterai deep cycle dapat discharge sampai dengan $80 \%$ kapasitas baterai. Dengan perencanaan kapasitas dan maintenance yang baik, baterai jenis ini dapat bertahan selama kurang lebih 10 tahun.

Tabel 1 Karakteristik lead acid berdasarkan standar

\begin{tabular}{lc}
\hline \hline \multicolumn{1}{c}{ Karakteristik } & Lead Acid \\
\hline Energi Spesifik $(\mathrm{Wh} / \mathrm{kg})$ & $30-50$ \\
Resistansi Internal $(\mathrm{m} \Omega)$ & Sangat Rendah \\
Siklus Hidup $(80 \%$ discharge $)$ & $200-300$ \\
Waktu Fast-Charge & $8-16$ jam \\
Toleransi Overcharge & Tinggi \\
Self-discharge per bulan & $5 \%$ \\
Tegangan Sel (nominal) & $2 \mathrm{~V}$ \\
Tegangan Cutoff Charge (V/cell) & 2.40 \\
& Float 2.25 \\
Tegangan Cutoff Discharge (V/cell, $1 \mathrm{C})$ & 1.75 \\
Arus Load Peak & $5 \mathrm{C}$ \\
best result & $0.2 \mathrm{C}$ \\
Suhu Charge & sampai $50{ }^{\circ} \mathrm{C}$ \\
Suhu Discharge & -20 sampai $50{ }^{\circ} \mathrm{C}$ \\
Perawatan & $3-6$ bulan \\
Keamanan & Suhu Stabil \\
Digunakan Sejak & Sekitar $1800-$ an \\
\hline \hline
\end{tabular}

\section{PERANCANGAN SIMULASI PENGISIAN OPTIMAL STASIUN PENGISIAN KENDARAAN LISTRIK}

\section{A. Perancangan Sensor Tegangan}

Rangkaian pembagi tegangan (voltage divider) digunakan untuk pembacaan data tegangan pada sistem monitoring baterai VRLA.

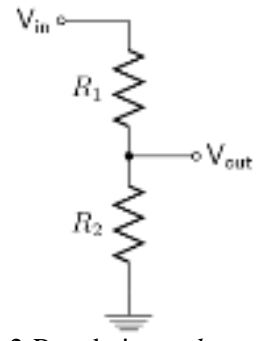

Gambar 2 Rangkaian voltage divider

Rangkaian voltage divider digunakan untuk membuat suatu tegangan referensi dari sumber tegangan yang lebih besar untuk titik tegangan referensi pada sensor. Hal ini dikarenakan tegangan baterai yang akan diukur adalah $25 \mathrm{~V}$, sedangkan pin ADC Arduino memiliki batasan pembacaan tegangan sebesar $5 \mathrm{~V}$. Oleh karena itu, rangkaian voltage divider digunakan untuk memperkecil tegangan sesuai dengan perbandingan yang telah dihitung dengan persamaan 3.2 berikut ini :

Vo $=$ Vbat $x\left(\frac{\mathrm{R} 2}{\mathrm{R} 1+\mathrm{R} 2}\right)$

Diasumsikan :

Vin $=30 \mathrm{~V}$ (tegangan baterai)

$\mathrm{Vo}=5 \mathrm{~V}$ (tegangan maksimal yang boleh masuk arduino)

$$
\mathrm{R} 2=20.000 \mathrm{ohm}
$$

Maka,

$$
\begin{aligned}
& 5=\frac{20.000}{R 1+20.000} 30 \\
& \mathrm{R} 1(5)+20.000(5)=600.000 \\
& 5 \mathrm{R} 1=500.000 \\
& \mathrm{R} 1=100.000 \mathrm{ohm} \approx 100 \mathrm{Kohm}
\end{aligned}
$$

Dari perhitungan diatas didapatkan nilai tahanan resistor yang digunakan untuk membuat rangkaian voltage divider dengan $\mathrm{R} 1=100 \mathrm{~K}$ ohm dan $\mathrm{R} 2=20 \mathrm{Kohm}$

\section{B. Perancangan Sensor Suhu}

Untuk mengambil data suhu pada sistem monitoring baterai VRLA ini digunakan sensor suhu dengan tipe LM35. Sensor ini memiliki fungsi untuk mengubah besaran suhu menjadi besaran listrik dalam bentuk tegangan. Selain memiliki tingkat akurasi dan kemudahan dalam merancang yang tinggi, sensor ini ini juga mempunyai keluaran impedansi yang rendah dan linieritas yang tinggi sehingga dapat dengan mudah dihubungkan dengan rangkaian kendali khusus serta tidak memerlukan penyetelan lanjutan.

\section{Perancangan Software Arduino}

Penggunaan Arduino MEGA pada desain monitoring baterai VRLA ini berfungsi mengubah pembacaan sinyal analog dari sensor menjadi sinyal digital. Sinyal digital inilah yang nantinya dapat diolah menjadi data yang diperlukan dalam sistem monitoring.

\section{Perancangan Fuzzy Logic Controller}

Ada tiga proses utama jika ingin mengimplementasikan fuzzy logic pada suatu perangkat, yaitu fuzzifikasi, evaluasi rule, dan defuzzifikasi.

1. Fuzzification, merupakan suatu proses untuk mengubah suatu masukan dari bentuk tegas (crisp) menjadi fuzzy yang biasanya disajikan dalam bentuk himpunanhimpunan fuzzy dengan suatu fungsi kenggotaannya masing-masing.

2. Interference System (Evaluasi Rule), merupakan sebagai acuan untuk menjelaskan hubungan antara variablevariabel masukan dan keluaran yang mana variabel yang diproses dan yang dihasilkan berbentuk fuzzy. Untuk menjelaskan hubungan antara masukan dan keluaran biasanya menggunakan "IF-THEN".

3. Defuzzification, merupakan proses pengubahan variabel berbentuk fuzzy tersebut menjadi data-data pasti (crisp) yang dapat dikirimkan ke peralatan pengendalian. 


\section{ANALISIS DAN PEMBAHASAN}

\section{A. Pengambilan data Charge dan Discharge Baterai VRLA di Charging Station ITS}

Simulasi Berikut ini adalah grafik hasil implementasi alat dengan proses charge-discharge yang berlangsung berturutturut meliputi tegangan baterai dan suhu.

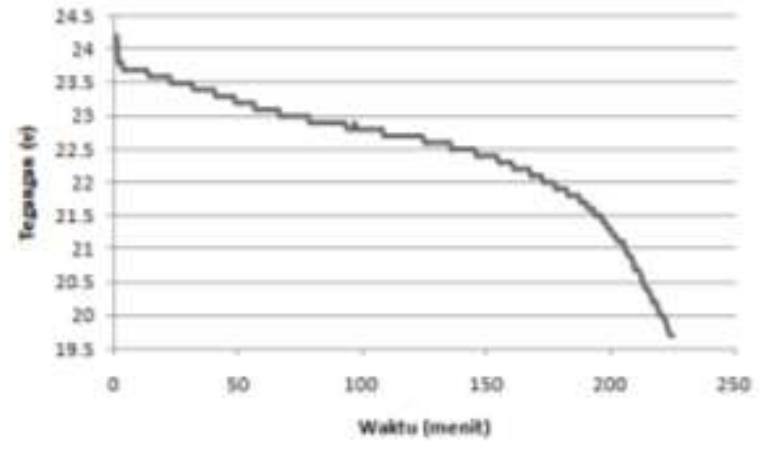

Gambar 3 Grafik tegangan saat discharge

Ketika baterai discharge, dapat dilihat pada grafik tegangan turun dengan konstan. Jika mengacu pada datasheet baterai, terlihat tegangan memiliki kisaran yang cenderung linear. Perbedaan grafik dapat dikarenakan proses discharge yang kurang sempurna dan kondisi baterai yang mulai berkurang kapasitasnya.

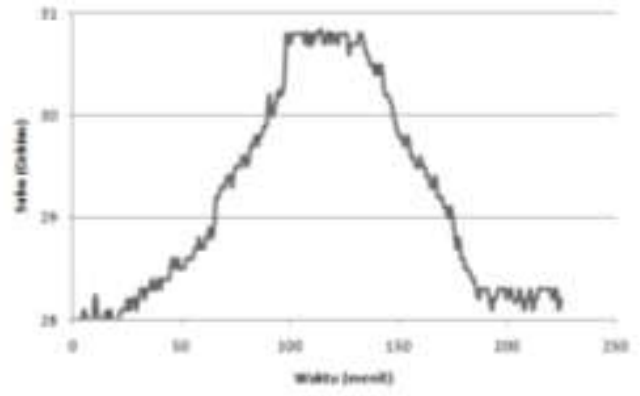

Gambar 4 Grafik suhu saat discharge

Dari grafik suhu saat discharge, dapat terlihat suhu semakin meningkat ketika semakin mendekati waktu discharge maksimal.

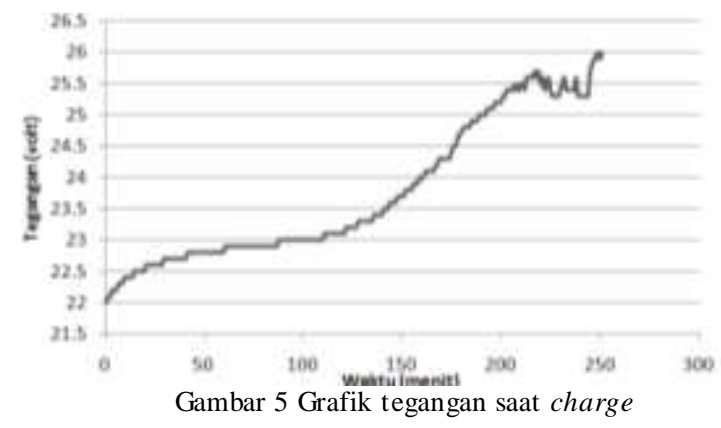

Pada kurva tegangan saat charge dapat dilihat tegangan pada grafik tegangan naik dengan konstan. Jika mengacu pada datasheet baterai, terlihat tegangan memiliki kisaran yang cenderung linear. Perbedaan grafik dapat dikarenakan proses charge yang kurang sempurna dan kondisi baterai yang mulai berkurang kapasitasnya. Terlihat tegangan baterai saat mendekati peak sempat tidak konstan. Hal itu menandakan baterai sudah mencapai kapasitas charge maksimal nya.

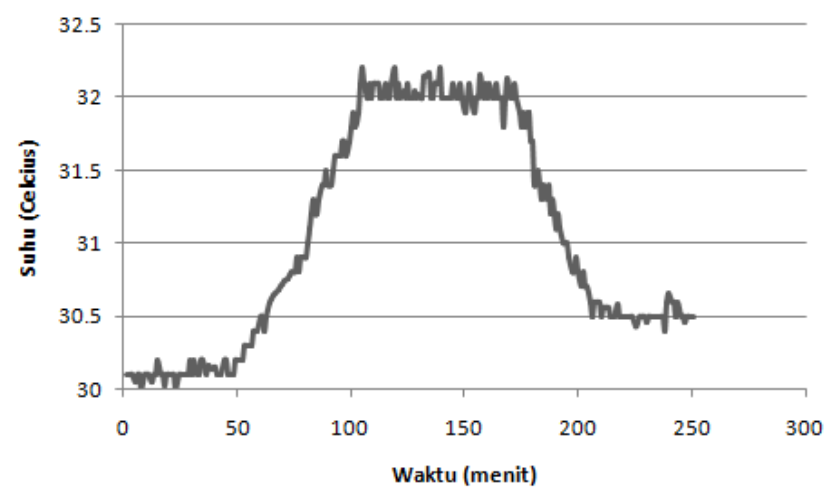

Gambar 6 Grafik suhu saat charge

Pada kurva grafik suhu saat charge, dapat dilihat suhu cenderung konstan sampai saat mendekati waktu ketika tegangan mencapai puncak (peak).

\section{B. Menentukan State of Charge berdasarkan Fuzzy Logic}

Dari hasil pengukuran charge dan discharge pada tegangan dan suhu baterai, untuk menentukan SOC digunakan metode logika fuzzy. Tahap pertama fuzzifikasi dengan menentukan setiap derajat keanggotaan untuk setiap set pada fuzzy. Dari pengukuran tegangan dan suhu sebelumnya, dapat ditentukan membership function.
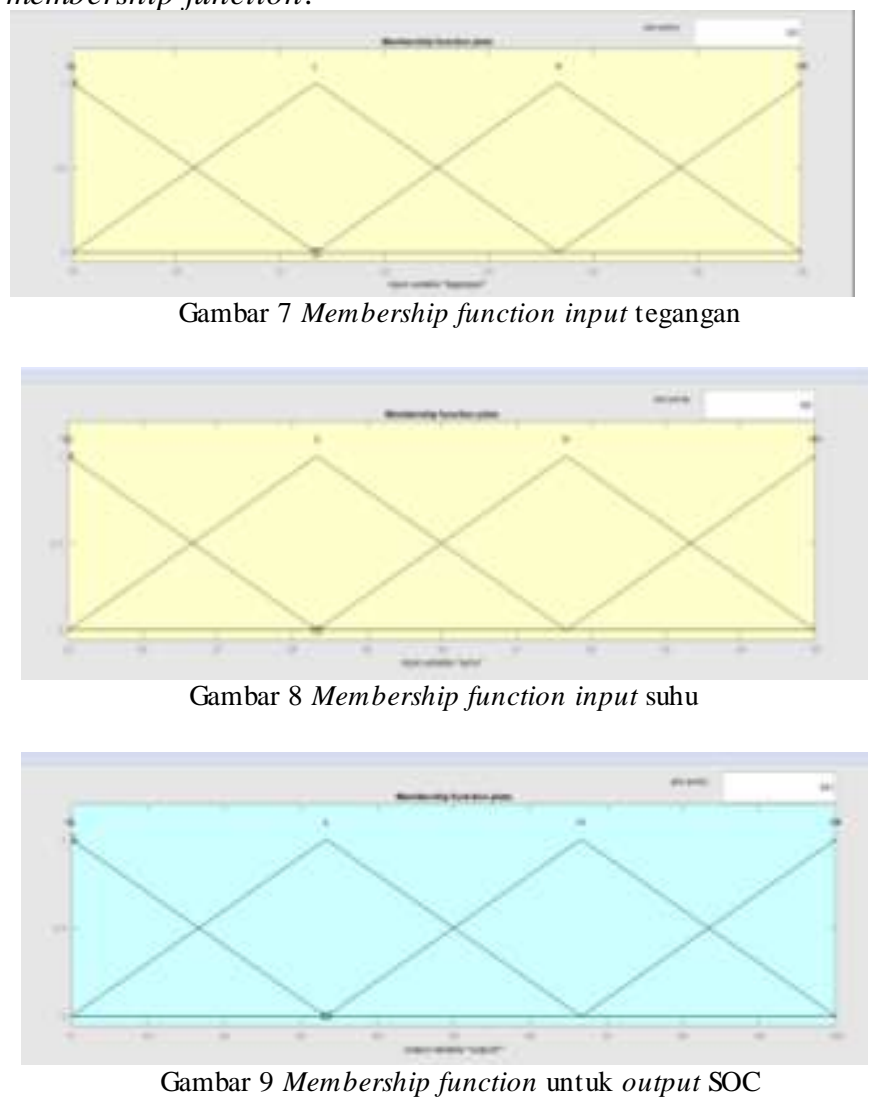

Membership function pada tegangan ditentukan dari data charge dan discharge pada tegangan di baterai charging station. Didapat tegangan bawah saat discharge adalah 20 volt. Digunakan batas bawah pada membership function tegangan 19 untuk mengantisipasi undervoltage. Batas atas membership function tegangan dilihat dari tegangan maksimum saat charge yaitu 25,5. Membership function yang digunakan adalah 26 . 
Membership function pada suhu digunakan suhu minimum adalah 25 derajat celcius dan suhu maksimum 36 derajat celcius. Membership function ditentukan berdasarkan data pengukuran suhu agar output dari fuzzy logic lebih akurat.

\section{Menentukan Aturan Logika Fuzzy}

Untuk menentukan aturan fuzzy logic, perlu dilakukan pengujian SOC terhadap tegangan dan SOC terhadap suhu. Setelah dilakukan pengujian didapat data sebagai berikut :

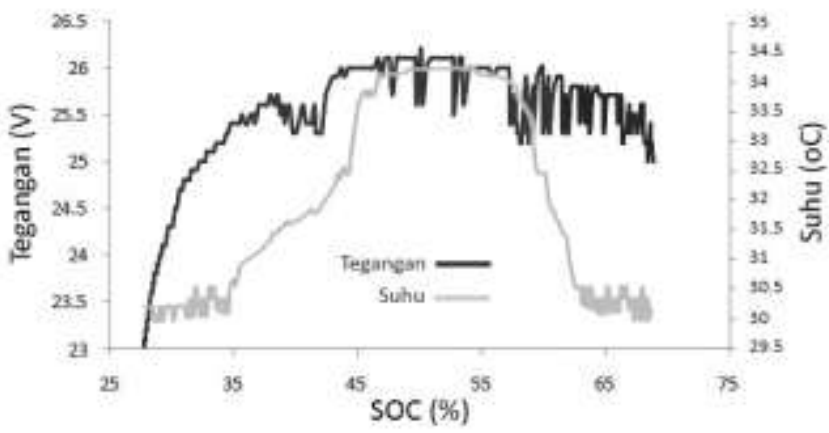

Gambar 10 Grafik tegangan, suhu, dan SOC saat charge

Dari gambar 9 dan 10 dapat dilihat kurva perbandingan tegangan, suhu, dan SOC. Ketika awal tegangan naik, suhu cenderung tetap, SOC naik, dan ketika tegangan turun, SOC juga menurun.

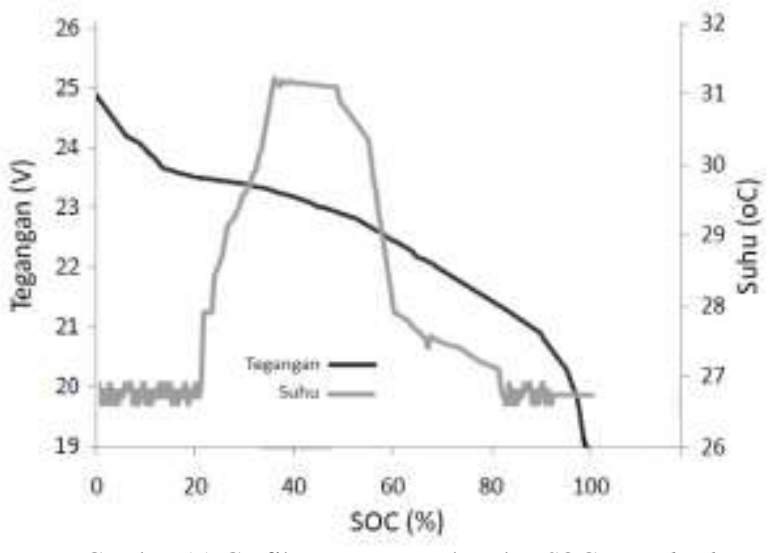

Gambar 11 Grafik tegangan, suhu, dan SOC saat discharge

Dari gambar 10, dapat dilihat kurva perbandingan suhu dan SOC. Saat charge, suhu cenderung tetap diawal, ketika mendekati kondisi SOC hampir penuh, suhu mengalami kenaikan. Dari gambar 11, dapat dilihat kurva perbandingan suhu dan SOC ketika kondisi baterai discharge. Saat discharge, suhu baterai saat awal cenderung tetap tetapi mengalami kenaikan saat SOC baterai berada di tengah.

Setelah melihat karakteristik SOC dengan tegangan dan suhu, dapat dibuat rule base. Untuk menentukan nilai state of charge yang terukur pada baterai di charging station ITS. Rule base pada tabel 4.4 adalah rule base dari tegangan dan suhu. Parameter yang terdapat pada tabel suhu adalah VL sebagai very low, L sebagai low, $\mathrm{H}$ sebagai high, VH sebagai very high.

Sedangkan parameter yang terdapat pada rule base suhu adalah VC sebagai very cold, C sebagai cold, $\mathrm{H}$ sebagai hot, VH sebagai very hot. Dari kedua tersebut dapat dipertimbangkan niai state of charge.
Pada parameter rule base SOC, VL sebagai very low, L sebagai low, H sebagai high, dan VH sebagai very high. Nilai SOC dipertimbangkan dari dua fuzzy logic rule yaitu ketika baterai mengalami proses charge dan ketika baterai mengalami kondisi discharge .

Dari gambar 10, dapat dilihat kurva perbandingan suhu dan SOC. Saat charge, suhu cenderung tetap diawal, ketika mendekati kondisi SOC hampir penuh, suhu mengalami kenaikan. Dari gambar 11, dapat dilihat kurva perbandingan suhu dan SOC ketika kondisi baterai discharge. Saat discharge, suhu baterai saat awal cenderung tetap tetapi mengalami kenaikan saat SOC baterai berada di tengah.

Setelah melihat karakteristik SOC dengan tegangan dan suhu, dapat dibuat rule base. Untuk menentukan nilai state of charge yang terukur pada baterai di charging station ITS. Rule base pada tabel 4.4 adalah rule base dari tegangan dan suhu. Parameter yang terdapat pada tabel suhu adalah VL sebagai very low, L sebagai low, $\mathrm{H}$ sebagai high, $\mathrm{VH}$ sebagai very high.

Sedangkan parameter yang terdapat pada rule base suhu adalah VC sebagai very cold, C sebagai cold, $\mathrm{H}$ sebagai hot, VH sebagai very hot. Dari kedua tersebut dapat dipertimbangkan niai state of charge.

Pada parameter rule base SOC, VL sebagai very low, L sebagai low, H sebagai high, dan VH sebagai very high. Nilai SOC dipertimbangkan dari dua fuzzy logic rule yaitu ketika baterai mengalami proses charge dan ketika baterai mengalami kondisi discharge.

Tabel 4.4 Tabel rule base tegangan dan suhu saat charge

\begin{tabular}{|c|c|c|c|c|}
\hline \multicolumn{2}{|l|}{ Voltage } & \multirow[b]{2}{*}{$\mathrm{L}$} & \multirow[b]{2}{*}{$\mathrm{H}$} & \multirow[b]{2}{*}{ VH } \\
\hline Temp & $\mathrm{VL}$ & & & \\
\hline $\mathrm{VC}$ & VL & $\mathrm{VL}$ & $\mathrm{L}$ & $\mathrm{H}$ \\
\hline $\mathrm{C}$ & VL & VL & $\mathrm{L}$ & $\mathrm{VH}$ \\
\hline $\mathrm{H}$ & $\mathrm{L}$ & VL & $\mathrm{L}$ & $\mathrm{H}$ \\
\hline $\mathrm{VH}$ & $\mathrm{L}$ & $\mathrm{L}$ & $\mathrm{H}$ & $\mathrm{H}$ \\
\hline
\end{tabular}

Tabel 4.5 Tabel rule base tegangan dan suhu discharge

\begin{tabular}{|c|c|c|c|c|}
\hline Temp & VL & $\mathrm{L}$ & $\mathrm{H}$ & $\mathrm{VH}$ \\
\hline $\mathrm{VC}$ & VL & $\mathrm{L}$ & $\mathrm{H}$ & VL \\
\hline $\mathrm{C}$ & VL & VL & $\mathrm{L}$ & $\mathrm{H}$ \\
\hline $\mathrm{H}$ & $\mathrm{L}$ & $\mathrm{L}$ & $\mathrm{L}$ & $\mathrm{VH}$ \\
\hline $\mathrm{VH}$ & $\mathrm{L}$ & $\mathrm{L}$ & $\mathrm{H}$ & $\mathrm{VH}$ \\
\hline
\end{tabular}

\section{Analisa hasil SOC}

Setelah membership function dan rule pada fuzzy telah ditentukan, dilakukan pengujian SOC pada saat kondisi charge dan discharge. Pengujian SOC pada baterai di charging station ITS dilakukan dalam dua tahap. Yaitu ketika baterai dalam kondisi tidak mendapat supply listrik dari photovoltaic (malam hari) dan kemudian dibebani hingga baterai mencapai titik minimum dan ketika baterai dalam kondisi mendapat supply listrik dari photovoltaic (siang hari) dalam keadaan 
tanpa beban dan besarnya supply listrik yang masuk bergantung pada sinar matahari.

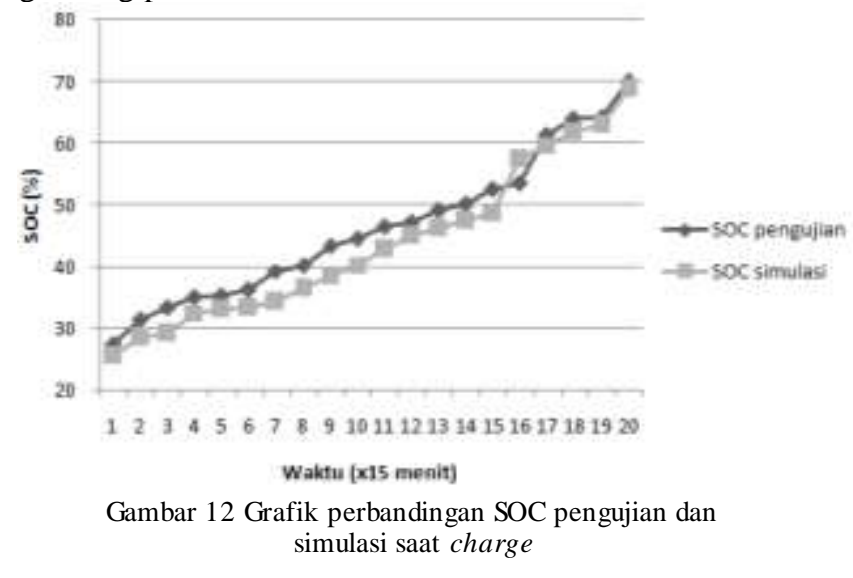

Pada kurva dapat dilihat pada grafik SOC saat charge memiliki pola naik yang linear sesuai dengan kondisi baterai yang di-charge sampai keadaan penuh. Didapat perbedaan yang tidak terlalu jauh dari kurva pengujian jika dibandingkan dengan kurva SOC saat simulasi

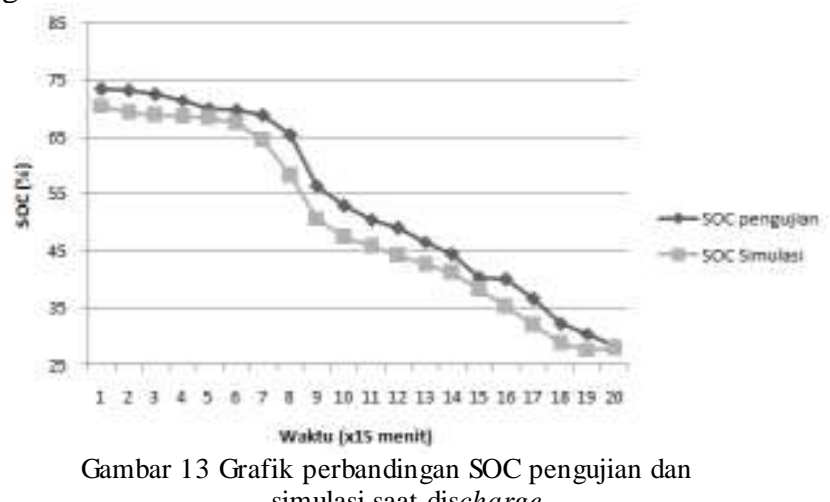

Pada kurva dapat dilihat pada grafik SOC saat discharge memiliki pola turun yang linear sesuai dengan kondisi baterai yang di-discharge sampai keadaan penuh. Didapat perbedaan yang tidak terlalu jauh dari kurva pengujian jika dibandingkan dengan kurva SOC saat simulasi.

\section{KESIMPULAN}

Pada tugas akhir ini telah didesain sistem monitoring pada baterai di stasiun pengisian kendaraan listrik ITS. Desain terdiri dari perangkat hardware dan software. Rangkaian monitoring baterai yang telah didesain mampu bekerja sesuai dengan sensor yang terpasang. Dari hasil pengujian dapat mengukur tegangan DC hingga 27 volt dengan tidak ada error dan mampu mengukur suhu dengan error $0,7 \%$. Untuk pembatasan suhu dibatasi sesuai dengan aturan standar baterai lead acid, yaitu $-20^{\circ} \mathrm{C}$ sampai $50^{\circ} \mathrm{C}$.

Desain sistem monitoring baterai menggunakan fuzzy logic telah dikembangkan pada penelitian ini yaitu, untuk mendapatkan nilai SOC akurat pada sistem monitoring.Untuk mengestimasi SOC digunakan 2 input membership function yaitu tegangan dan suhu baterai.

Interface monitoring baterai yang dibangun menggunakan Arduino telah mampu melakukan pembacaan terhadap nilai yang disensing oleh masing-masing sensor. Data yang didapatkan dari monitoring ini berupa data logger. Sehingga diperoleh nilai dari masing-masing sensor secara realtime.

\section{DAFT AR PUST AKA}

[1] Faria, Ricardo. Moura, Pedro. dan Delgado, Joaquim. 21 Juli 2014, "Managing the charging of Electrical Vehicle : Impacts on the Electrical Grid and on the Enviromental". Intelligent Transportation Systems Magazine IEEE Volume 6, http://ieeexplore.ieee.org/, diakses 9 Desember 2014

[2] Batteryuniversity Admin, 2014. "BU-401 a: Fast and Ultra-fast Chargers". http://batteryuniversity.com/learn/article/, diakses 9 Desember 2014

[3] Yarlagadda, S., Hartley, T.T. dan Husain, I. 23 Mei 2013 “A Battery Management System Using an Active Charge Equalization Technique Based on a DC/DC Converter Topology". Industry Applications, IEEE Transactions on Volume: 49 , http://ieeexplore.ieee.org/, diakses 9 Desember 2014

[4] David, Linden and Reddy, Thomas B. 2001, Handbook Of Batteries, $3^{\text {th }}$ Edition, The McGraw-Hill Companies, Inc 